\title{
MÁLFREGNIR
}

\section{CLARIN-miðstöð á Stofnun Árna Magnússonar í íslenskum fræðum}

\section{Inngangur}

Síðla árs 2018 fól mennta- og menningarmálaráđuneytið Stofnun Árna Magnússonar í íslenskum fræðum að hafa forystu um pátttöku Íslands í evrópska rannsóknarinnviðaverkefninu CLARIN ERIC (https://www.clarin.eu/) - CLARIN stendur fyrir "Common Language Resources and Technology Infrastructure" og ERIC stendur fyrir „European Research Infrastructure Consortium“. CLARIN ERIC er undir hatti Evrópusambandsins og starfar eftir sampykktum sem hafa verið staðfestar af framkvæmdastjórn pess.

Flest ríki Evrópu taka pátt í pessu samstarfi, p. á m. öll Norðurlönd, og ber mennta- eða vísindamálaráđuneyti hvers ríkis yfirleitt ábyrgð á pátttökunni. Ráðuneytið felur síðan einni stofnun að hafa forystu um pátttöku ríkisins í CLARIN ERIC og standa fyrir myndun landshóps (e. national consortium) helstu hagsmunaaðila, einkum háskóla og rannsóknarstofnana, en sums staðar einnig málnefnda, landsbókasafna og annarra safna. Ráðuneytið tilnefnir einnig landsfulltrúa (e. national coordinator) sem er yfirleitt starfsmaður forystustofnunarinnar og stýrir starfinu í viðkomandi landi. 


\section{Hvað er CLARIN ERIC?}

CLARIN ERIC er stofnað til að halda utan um stafræna innviði gögn og hugbúnað - til nota við rannsóknir í félags- og hugvísindum. Eftir að almenn tölvuvæðing hófst fyrir 40 árum eða svo hefur orðið til gífurlega mikið af stafrænum gögnum af ýmsu tagi - textasöfn, orðasöfn, og alls kyns skrár. Sumt af pessu hefur verið byggt upp frá grunni á undanförnum áratugum, en einnig hefur verið gert mikið átak í pví að koma eldri gögnum á stafrænt form.

Stafræn gögn bjóða vitaskuld upp á margvíslega möguleika umfram pappírsgögn. Рað er margfalt fljótlegra að leita í peim og vinna ýmiss konar skrár og töflur upp úr peim. Stafræn gögn eru líka margfalt sveigjanlegri en pappírsgögn - auðvelt að lagfæra villur í peim, uppfæra pau, raða peim á mismunandi hátt o.s.frv. Notendur eru ekki lengur háðir einu eintaki á tiltekinni stofnun eða safni - pað er auðvelt að afrita gögnin og dreifa peim, eða gera pau aðgengileg á netinu.

Petta stórbætta aðgengi að gögnum leiðir vitanlega til pess að miklu fleiri fræðimenn geta nýtt pau en áður, og eflir pannig og styrkir margvíslegar rannsóknir. En petta pýðir líka að fólk er oft að skoða og vinna með gagnasöfn sem pað pekkir ekki fyrir. Söfnin eru mjög margbreytileg, framsetning peirra misjöfn, leitarmöguleikar ólíkir, og svo mætti lengi telja. Рað getur verið mjög flókið og tímafrekt fyrir ókunnuga að setja sig inn í petta og átta sig á pví hvernig hægt er að finna pað sem leitað er að í gögnunum.

Meginmarkmið CLARIN ERIC er að nýta pá möguleika sem stafræn málleg gögn, málföng (e. language resources), bjóða upp á og bæta aðgengi að pessum gögnum og hugbúnaði sem gerður er til að vinna með pau. Petta krefst margvíslegs undirbúnings sem mikilvægt er að sem víðtækust samvinna sé höfð um. Jafnframt er markmið CLARIN ERIC að notendur geti nýtt notandanafn og aðgangsorð við heimastofnun sína til að fá aðgang að pessum gögnum og búnaði (e. single sign-on).

Í hverju pátttökulandi eru settar upp CLARIN-miðstöðvar, ein eða fleiri. Pessar miðstöðvar eru af mismunandi tegundum. Einfaldasta tegundin eru svokallaðar C-miðstöðvar (e. CLARIN C-Centre) sem varðveita lýsigögn (e. metadata), en aðaltegundin er svokallaðar B-miðstöðvar (e. CLARIN B-Centre) sem varðveita gögn ásamt lýsigögnum og veita ákveðna pjónustu, s.s. upplýsingar um gögn og tæknilega ráðgjöf. Priðja tegundin er svo K-miðstöðvar (e. CLARIN K-Centre) sem eru upplýsingaveitur um tiltekin málleg efni, t.d. einstakt tungumál. 


\section{Gögn í CLARIN ERIC}

Áður en gögn eru skráð í miðlægan gagnagrunn CLARIN ERIC parf í fyrsta lagi að útbúa lýsigögn par sem innihaldi gagnanna er lýst og upplýsingar gefnar um ýmis atriði sem pau varða - höfunda, tungumál, gagnasnið, notkunarskilmála o.s.frv. Pessi lýsigögn purfa að vera á samræmdu sniði til að auðvelda notkun peirra og leit í peim. CLARIN ERIC hefur útbúið sniðmát fyrir lýsigögn til að leiðbeina notendum um hvaða upplýsingar purfi að fylgja gögnunum.

Í öðru lagi parf að ákveða notkunarskilmála gagnanna - hvort pau eru öllum opin og aðgengileg án takmarkana, eða hvort einhverjar takmarkanir eru á aðgengi og notkun, og pá hverjar. Рað er t.d. algengt að óheimilt sé að nýta gögn í hagnaðarskyni eða breyta peim á einhvern hátt. Til eru ýmsir staðlaðir leyfisskilmálar sem hægt er að velja á milli, t.d. svonefnd Creative Commons-leyfi (https://creativecommons. org/), en einnig er hægt að gera gögn aðgengileg með sérsniðnum leyfum.

Í priðja lagi getur purft að breyta gagnasniðinu. Ýmis samræmd snið hafa verið sett fram fyrir mismunandi tegundir mállegra gagna - textasöfn, orðasöfn, handrit, uppskriftir hljóðskráa o.s.frv. Par má ekki síst nefna margvísleg snið frá Text Encoding Initiative (https://tei-c. org/). Æskilegt er að gögn séu á einhverju slíku pekktu sniði eftir pví sem kostur er, en lágmarkskrafa er að sniði gagnanna sé nákvæmlega lýst pannig að auðvelt sé fyrir notendur að átta sig á pví.

Í fjórða lagi parf að gera gögnin aðgengileg, ásamt lýsigögnum. Рað er hægt að gera á ýmsan hátt. Að sumum gögnum er eingöngu leitaraðgangur gegnum ákveðið leitarviðmót. Notendur geta pá leitað að orðum og orðasamböndum en pað er misjafnt eftir gagnasniði og leitarviðmóti hversu nákvæm leitin getur verið, og eftir hvaða atriðum er hægt að leita. Í öðrum tilvikum er hægt að sækja gögnin í heild, stundum með ákveðnum skilyrðum sem kveðið er á um í leyfisskilmálum sem parf að sampykkja áður en gögnin eru sótt.

Miðlægt tölvukerfi CLARIN ERIC skannar reglulega allar lýsigagnaskrár sem vistaðar eru á öllum CLARIN-miðstöðvum. Upplýsingar úr pessum skrám fara inn í miðlægan gagnagrunn, sýndarsafn málfanga (e. Virtual Language Observatory, https://vlo.clarin.eu/) og par er hægt í einni leit að leita ílýsigögnum meira en milljón málfanga um alla Evrópu. Öllum gögnum sem eru lögð inn til einhverrar CLARINmiðstöðvar er gefið varanlegt auðkenni (e. Persistent Identifier, PID). 
Pað tryggir að ávallt sé hægt að finna gögnin enda pótt vistun peirra og hefðbundin vefslóð (URL) kunni að breytast.

\section{4 Ísland og CLARIN ERIC}

Upphaf CLARIN má rekja aftur til 2008 pegar undirbúningsfasi pess hófst. Ísland var ekki með frá byrjun en komst inn í samstarfshóp undirbúningsfasans árið 2010, en án fjárhagslegs stuðnings. Pegar eðli CLARIN breyttist árið 2012 og CLARIN ERIC varð til varð Ísland ekki stofnaðili. Íslandi var pó boðin pátttaka í sérstöku norrænu CLARINneti, Nordic CLARIN Network, sem kostað var af NordForsk á árunum 2014-2017. Íslenskir fræðimenn tóku pátt í ýmsum fundum og vinnustofum sem netið skipulagði.

Í verkáætlun um íslenska máltækni sem gefin var út sumarið 2017 er sérstakur kafli um CLARIN. Par er útskýrt hvernig aðild myndi gagnast Íslandi, með aðgangi að margvíslegum búnaði og gögnum, svo og að sérpekkingu á ýmsum sviðum. Innan máltækniáætlunarinnar á að próa margs kyns gögn og búnað og pað er mjög mikilvægt að gerð, lýsing og varðveisla pessara málfanga fylgi viðurkenndum stöðlum. Í áætluninni var pví lagt til að Ísland gerðist aðili að CLARIN ERIC til að auðvelda vinnslu og varðveislu málfanganna.

Mennta- og menningarmálaráðuneytið féllst á pessa tillögu og ákvað að fjármagna pátttöku Íslands í CLARIN ERIC til fimm ára. Pað kom pó í ljós að nauðsynlegt væri að breyta lögum til að Ísland gæti orðið fullgildur aðili og pví var ákveðið að sækja um áheyrnaraðild (e. observership). Umsóknin var sampykkt á allsherjarpingi CLARIN ERIC í nóvember 2018 og áheyrnaraðild Íslands tók gildi 1. nóvember pað ár.

Ráðuneytið fól Stofnun Árna Magnússonar í íslenskum fræðum að vera fulltrúi Íslands gagnvart CLARIN ERIC og leiðandi aðili (e. leading partner) í íslenskum CLARIN-landshópi, eins og áður segir. Eiríkur Rögnvaldsson, prófessor emerítus, var tilnefndur landsfulltrúi CLARIN á Íslandi. Flestar stofnanir sem málið varðar taka pátt í landshópi CLARIN-IS. Auk Stofnunar Árna Magnússonar í íslenskum fræðum eru pað Háskóli Íslands, Háskólinn í Reykjavík, Landsbókasafn Íslands - Háskólabókasafn, Pjóðskjalasafn Î́slands, Íslensk málnefnd, Ríkisútvarpið, og Almannarómur.

CLARIN-miðstöðin á Árnastofnun, CLARIN-IS (https://clarin.is/), tók til starfa í ársbyrjun 2019. Par starfa Eiríkur Rögnvaldsson landsfulltrúi í 40\% starfi og frá 1. apríl sama ár Samúel Pórisson tölvunar- 
fræðingur í fullu starfi. Meginverkefni miðstöðvarinnar hafa verið tvö: Annars vegar pátttaka í samstarfi CLARIN ERIC, og hins vegar uppbygging varðveislusafns (e. repository) sem komst í gagnið síðla árs (https://repository.clarin.is/). CLARIN-miðstöðin hefur einnig verið skráð sem lýsigagnamiðstöð (e. CLARIN C-Centre).

Í júní 2019 voru ný lög um samtök evrópskra rannsóknarinnviða sampykkt á Alpingi. Í framhaldi af pví ákvað mennta- og menningarmálaráðherra snemma árs 2020 að Ísland sækti um fulla aðild að CLARIN ERIC. Umsóknin var sampykkt í lok febrúar og Ísland er fullgildur aðili að CLARIN ERIC frá 1. febrúar 2020 en gengið var frá undirritun aðildarsamnings 10. mars. CLARIN-miðstöðin, sem hafði verið í húsnæði Árnastofnunar á Laugavegi 13, er nú flutt í Pingholtsstræti 29 par sem máltæknihópur Árnastofnunar hefur aðsetur.

\section{Starfsemin fram undan}

Pótt megintilgangurinn með stofnun CLARIN ERIC hafi verið að styðja rannsóknir í hug- og félagsvísindum nýtast pau gögn sem komið hefur verið upp á ýmsum öðrum sviðum, ekki síst í máltækni sem er í örum vexti víðast hvar. Eins og áður segir er aðild Íslands að CLARIN ERIC fjármögnuð af máltækniáætlun stjórnvalda og í samningum Almannaróms f.h. ríkisins við SÍM - samstarf um íslenska máltækni, sem vinnur að framkvæmd máltækniáætlunarinnar, eru ákvæði um að allar afurðir máltækniverkefnisins, bæði gögn og hugbúnaður, verði lagðar inn í varðveislusafn íslensku CLARIN-miðstöðvarinnar.

Petta er grundvallaratriði. Ein meginforsenda máltækniáætlunarinnar er að afurðir hennar verði öllum aðgengilegar og ókeypis, pannig að fyrirtæki og stofnanir sem vilja nýta pær við próun máltæknibúnaðar geti gengið að peim sér að kostnaðarlausu. Pví er mjög mikilvægt að hægt sé að ganga að peim á einum stað, ítarleg lýsing á peim liggi fyrir, og pær séu á pekktu og vel skilgreindu sniði. Innlögn í CLARIN-miðstöðina tryggir petta allt saman.

Fyrstu afurðum máltækniverkefnisins hefur pegar verið skilað og pær skráðar í safnið. Par geta CLARIN-notendur hvar sem er fundið pær gegnum áðurnefnt sýndarsafn málfanga, og sótt pær pangað. Skráning gagna Árnastofnunar í varðveislusafnið er einnig hafin og verður unnið að henni á næstunni. Að pví loknu verður farið að huga að skráningu gagna annarra pátttakenda í íslenska landshópnum í varðveislusafnið. 
Fullgildum pátttakendum í CLARIN ERIC er skylt að koma upp a.m.k. einni tæknilegri pjónustumiðstöð (e. CLARIN B-Centre). CLARINIS vinnur að pessu en pað er töluvert mál - slík miðstöð parf að fullnægja ýmsum skilyrðum og fá sérstaka vottun. Auk pess er áhugi á pví hjá íslensku CLARIN-miðstöðinni að koma upp pekkingarmiðstöð (e. CLARIN K-Centre) um íslenskt mál, par sem hægt væri að sækja hvers kyns gögn og upplýsingar um íslensku. Undirbúningur pessa er á frumstigi, en slík miðstöð yrði hugsanlega rekin í samvinnu við aðra aðila, t.d. Íslenska málnefnd sem hefur lýst áhuga á pví að koma upp upplýsingaveitu af pessu tagi.

Einnig liggur fyrir að kynna CLARIN fyrir hugsanlegum notendum, einkum fræðimönnum í ýmsum greinum hug- og félagsvísinda. Гаð er ljóst að innan CLARIN ERIC eru margvísleg gögn, innlend og erlend, sem geta gagnast málfræðingum, bókmenntafræðingum, sagnfræðingum, heimspekingum, félagsfræðingum, mannfræðingum, stjórnmálafræðingum, pjóðfræðingum, og mörgum öðrum. Fáir vita hins vegar af pessum gögnum og peim möguleikum sem í peim felast, og pað er hlutverk CLARIN-miðstöðvarinnar að kynna petta.

Enn fremur er stefnt að öflugri pátttöku í ráðstefnum og viðburðum á vegum CLARIN ERIC. Sú pátttaka er pegar hafin - sjö Íslendingar sóttu ársráðstefnu CLARIN ERIC í Leipzig haustið 2019 og voru par með einn fyrirlestur og prjú veggspjöld. CLARIN ERIC kostar pátttöku fimm fulltrúa frá hverju aðildarlandi, auk peirra sem eru með erindi eða veggspjöld. Einnig er einum doktorsnema frá hverju landi boðin pátttaka sér að kostnaðarlausu. Auk pessa stendur CLARIN ERIC fyrir vinnustofum af ýmsu tagi sem Íslendingar geta nú sótt - og eru pegar farnir að gera.

\section{Lokaorð}

Mikilvægi stafrænna gagna í hvers kyns rannsóknum í hug- og félagsvísindum hefur aukist hröðum skrefum á undanförnum árum. Par nægir að nefna vefinn Tímarit.is, sem óhætt er að segja að hafi gerbreytt aðstöðu til rannsókna á íslenskri málfræði og sögu, svo að dæmi séu tekin. Risamálheildin (https://malheildir.arnastofnun.is/) hefur einnig nýst á margvíslegan hátt á peim stutta tíma sem liðinn er síðan hún var opnuð. En fjölmörg önnur íslensk málleg gagnasöfn eru til pótt ekki séu pau jafnpekkt eða aðgengileg. 
Pað er hlutverk íslensku CLARIN-miðstöðvarinnar að gera íslensk málföng sem aðgengilegust og vekja athygli á notagildi peirra. Að pví verður unnið eftir megni á næstu árum.

Eiríkur Rögnvaldsson

landsfulltrúi CLARIN

Stofnun Árna Magnússonar í íslenskum fræðum 
